\title{
Quadricoccopsis gen. nov., a new genus of Quadricoccus-like algae in Oocystaceae from China (Trebouxiophyceae, Chlorophyta)
}

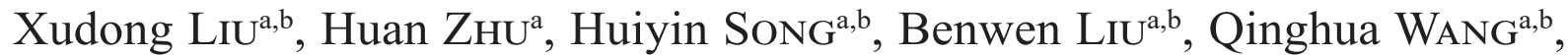 \\ Guoxiang LIU ${ }^{\mathrm{a}^{*}} \&$ Zhengyu Hu${ }^{\mathrm{c}}$
}

\author{
${ }^{a}$ Key Laboratory of Algal Biology, Institute of Hydrobiology, Chinese Academy of Sciences, Wuhan 430072, P.R \\ China; *Corresponding authore-mail:liugx@ihb.ac.cn \\ ${ }^{b}$ University of Chinese Academy of Sciences, Beijing 100049, P.R China \\ ' State Key Laboratory of Freshwater Ecology and Biotechnology, Institute of Hydrobiology, Chinese Academy \\ of Sciences, Wuhan 430072, China
}

\begin{abstract}
Members of Quadricoccus-like algae are characterized by oval to ellipsoid cells adherent to the bowl-shaped or stretched, empty mother cell walls and are common in phytoplankton of inland waters. To date, the morphologically similar genera Quadricoccus and Lobocystis are accepted for this group and the former had been phylogenetic positioned in Oocystaceae. In this study, seven strains of Quadricoccus-like algae were identified and successfully cultured in the laboratory. Light and electron microscope observations and phylogenetic analysis revealed that the strains represent three different species within a new genus, described here as Quadricoccopsis gen. nov. It differed from genus Quadricoccus by characteristically cell adherent mode that two pairs of daughter cells connected to the mother cell remnant respectively by the pole and median portion and distinguished from Lobocystis by variable 2-4-8 autospores, characteristically cell adherent mode and only found in limnetic water. The three new species, described here as Q. simplex, Q. parva and Q. glomerata, differed in cell size, colony morphology and autospore number. Phylogenetic analysis revealed the genus Quadricoccopsis in Oocystaceae and a close relationship with Oocystidium, which is far away from the phylogenetic position of Quadricoccus in one of the granulated clades. The Quadricoccus-like algae were, therefore, proved to be a paraphyly. Furthermore, apart from Planctonema-like algae, the Oocystaceae characteristic cell wall ultrastructure, which is multi-layered with cellulose fibrils in each layer perpendicular to those of the adjoining layer, is not shown again in genus Quadricoccopsis. Different cell wall substructures may be related to the colony formation mechanism. Whether the ultrastructure criterion is applied to all the Oocystaceae needs to be re-evaluated and, further, the definition of this family should be discussed.
\end{abstract}

Key words: Cell wall ultrastructure, Oocystaceae, Quadricoccopsis simplex, Quadricoccopsis parva, Quadricoccopsis glomerata, Quadricoccus

\section{INTRODUCTION}

Members of Quadricoccus-like algae are characterized by oval to ellipsoid cells adherent to the bowl-shaped or stretched empty mother cell walls by either the median or end portion (KOMÁREK \& FOTT 1983), which represent a common morphotype of coccoid green algae in phytoplankton of inland waters. The remnants of mother cell walls develop a system of stems connecting the individual cells to colonies and thus play a vital role in such morphotype. They were included in the genus Quadricoccus Fott and Lobocystis Thompson up to now. According to THOMPSON (1952), the Quadricoccuslike members resembled those grouped in the genera Dictyosphaerium Nägeli, Dichotomococcus Korshikov and Dimorphococcus Braun. KomÁReK \& FotT (1983) placed the genera Quadricoccus, Lobocystis, Dictyosphaerium, Dichotomococcus and two different genera Dactylosphaerium Steinecke and Dimorphococcopsis Jao into the subfamily Dictyospaerioideae. They were all characteristically distinguished by mother cell wall remnant connections in colony formation. Among them, members in genus Quadricoccus and genus Lobocystis share a similar oval to cylindrical cell shape and thus were often confused by previous researchers (HINDÁK 1977; KomÁREK \& FOTT 1983).

The genus Quadricoccus was first erected by Fотт in 1948 with type species $Q$. verrucosus Fott. Then, another 3 species were described based on smooth (Q. laevis Fotт and Q. ellipticus Новтов) or warty ( $Q$. 
verrucosus and $Q$. ovalis Hindák) cell walls and the adherent portion of the daughter cells on the empty wall of the mother cell ( $Q$. verrucosus and $Q$. laevis adhere by the ends whereas $Q$. ellipticus and $Q$. ovalis adhere by the median portion). However, the surface incrustations on the warty species $(Q$. verrucosus and $Q$. ovalis) were always considered doubtful (WILliams 1967; HINDÁK 1977; HINDÁK 1984; HINDÁK 1988; KRIENITZ \& BocK 2011). According to the observation of $Q$. ovalis by HiNDÁK (1984), the granulation density on the cell wall varied considerably in both the vegetative cells and the empty cell walls: from smooth walls without conspicuous granules to warty walls with dense granulation along the entire surface. Hindák further speculated that the intensity of granulation on $Q$. ovalis was obviously dependent on the chemistry of water in his later study (HINDÁK 1988). Though the dispute had always existed, all the species were accepted by most researchers. In 1998, a new species, Q. euryhalinicus Kuylenstierna, was proposed for characteristically having typically two autospores attached at each end of a tubular mother cell wall (KUYLENSTIERNA \& KARLSON 1998). Up to now, five species have been accepted based on the Algaebase (GUIRY \& GUIRY 2017). Recent studies by KRIENITZ \& Bock (2011) and ŠTenCloví et al. (2017) positioned the genus Quadricoccus in Oocystaceae (Trebouxiophyceae) as a sister to the genus Amphikrikos Korshikov.

The genus Lobocystis, erected by THOMPSON in 1952 with original type species Lobocystis dichotoma, shared a similar morphology with Quadricoccus, especially with the two-celled groups of Q. ellipticus (HINDÁK 1977; Comas \& Perez 2002). Later, FotT (1975) pointed the L.dichotoma was identical with Dictyosphaerium planctonicum Tiffany et Ahlstrom and proposed the combined type species Lobocystis planctonica (Tiffany et Ahlstrom) Fott. However, HINDÁK considered the Dictyosphaerium planctonicum and Lobocystis dichotoma var. mucosa BOURRELLY could not be included in Lobocystis since the daughter cells did not remain enclosed in the mother cell wall (HINDÁK 1977) Later, HiNDÁK proposed a possible generic feature of Lobocystis that reproduction by only 2 autospores (Hindák 1988). Then, CoMAS \& PEREZ (2002) supported this point and supplemented the demarcation of Lobocystis by basically formed by bi-celled groups enclosed in the mother cell wall and cells with 1-2 large parietal pyrenoid-bearing chloroplasts. HINDÁK (1977) implied that these two species might belong to Quadricoccus. However, KoMÁREK \& FOTT (1983) considered that this point should still be investigated and at least Lobocystis dichotoma var. mucosa was sufficiently independent to be a well-defined species. In addition, a Lobocystis sp. sensu Komárek (KoMÁreK \& FoTT 1983; IZAGUIRRE 1991) also seemed not belong to this genus because of the 4-celled colony. Though similar to $Q$. ellipticus (mentioned by KomÁreK \& FOTT 1983), this species seemed to distinguish itself with two pairs of cells connected to the mother cell wall by the median and end portion respectively. Though the disputes were still on the type species of genus Lobocystis, a formal taxonomic emendment of the genus was not made by either Hindák or CoMAs \& PEREz. Therefore, the meaning of FotT (1975) is still accepted (COMAS \& Perez 2002). Subsequently, apart from the type species, four extra recognisable species were proposed into Lobocystis (Izaguirre 1991; Comas \& Perez 2002; Stoyneva 2008; FANÉs et al. 2009). The phylogenetic position of Lobocystis has not been studied up to now.

In this study, seven strains, which share a similar morphology with the genera Quadricoccus and Lobocystis, were collected in China. Morphological and phylogenetic analyses identified these strains to be a new genus, Quadricoccopsis gen. nov., with three different new species.

\section{Material ANd Methods}

Quadricoccopsis simplex samples (strain LXD53) were collected from the Yingze Lake in Yingze Park $\left(37^{\circ} 51^{\prime} \mathrm{N}, 112^{\circ} 33^{\prime} \mathrm{E}\right.$, alt. 792 m, Taiyuan, Shanxi Province, China, in Aug. 2015). Three strains of Quadricoccopsis parva were respectively sampled in a fish pond (strain LXD126, $25^{\circ} 42^{\prime} \mathrm{N}, 115^{\circ} 36^{\prime} \mathrm{E}$, alt. $161 \mathrm{~m}$, Huichang, Jiangxi Province, China, in Feb. 2017), an artificial pond in a botanical garden (strain LXD135, $21^{\circ} 55^{\prime} \mathrm{N}$, $101^{\circ} 15^{\prime} \mathrm{E}$, alt. 546, Jinghong, Yunnan Province, China, in Apr. 2017) and an artificial pond at the roadside (strain LXD143, $31^{\circ} 6^{\prime} \mathrm{N}, 115^{\circ} 42^{\prime} \mathrm{E}$, alt. 348, Luotian, Hubei Province, China, in Aug. 2017). Three Quadricoccopsis glomerata were strain LXD117 (collected from the same fish pond with strain LXD126, $25^{\circ} 42^{\prime} \mathrm{N}, 115^{\circ} 36^{\prime} \mathrm{E}$, alt. $161 \mathrm{~m}$, Huichang, Jiangxi Province, China, in Feb. 2017), strain LXD134 (collected from the same artificial pond with strain $\mathrm{LXD} 135,21^{\circ} 55^{\prime} \mathrm{N}, 101^{\circ} 15^{\prime} \mathrm{E}$, alt. 546, Jinghong, Yunnan Province, China, in Apr. 2017) and strain LXD144 (collected from a fish pond at the roadside, $30^{\circ} 55^{\prime} \mathrm{N}$, $115^{\circ} 31^{\prime} E$, alt. 120 , Luotian, Hubei Province, China, in Aug. 2017). Two additional Oocystaceae samples were identified and sequenced herein for phylogenetic analysis.

Samples were isolated into a single colony using the serial dilution pipetting technique (HosHaw \& RosowsKi 1973) and maintained in liquid BG11 medium (STANIER et al. 1971) with a constant light source of $30-50 \mu \mathrm{mol} \cdot \mathrm{m}^{-2} . \mathrm{s}^{-1}$ and a temperature of $25^{\circ} \mathrm{C}$. Photomicrographs were taken on an Olympus BX53 light microscope (Olympus Corp., Tokyo, Japan) equipped with an Olympus BX53 camera. For transmission electron microscopy (TEM), cells were fixed in $3 \%$ glutaraldehyde in $0.1 \mathrm{M}$ cacodylate buffer and fixed in $1 \%$ aqueous $\mathrm{OsO}_{4}$ in 0.1 $\mathrm{M}$ cacodylate buffer, dehydrated in acetone and embedded in Spurr's resin. Ultrathin sections were stained with uranyl acetate and lead citrate (REYNOLDs 1963). The induction of zoospores and gametes was performed by flooding and light starvation (FuČíkoví et al. 2013).

Algal cells were broken with mini beads in a bead beater (3110BX, Biospec Products, Bartlesville, USA). Total DNA was extracted using a Universal DNA Isolation Kit (AxyPrep, Suzhou, China). Primers and PCR conditions for the $18 \mathrm{~S}$ rDNA and $r b c \mathrm{~L} c \mathrm{cpNA}$ genes were previously described in XIA et al. (2013).

The seven strains were aligned with 110 sequences of representative species of Trebouxiophyceae downloaded from GenBank. The sequences were initially aligned using ClustalX v 2.0 (LARKIN et al. 2007). Phylogenies were estimated using 
maximum likelihood (ML) in RAxML v.8.0 (STAMATAKIs 2014) and Bayesian inference (BI) in MrBayes 3.1.2 (HuELSENBECK \& RoNQUIST 2001). For ML analysis, GTRGAMMA was selected as the best-fit model. The different substitution models of each partition used in the BI analyses were selected by MrModeltest 2.3 (NyLANDER 2004). The best-fit models applied to MrBayes were $\mathrm{GTR}+\mathrm{I}+\mathrm{G}$ for the $18 \mathrm{~S}$ rDNA dataset and $\mathrm{GTR}+\mathrm{G}$ for the $r b c \mathrm{~L}$ cpDNA. All Markov Chain Monte Carlo (MCMC) analyses were performed with seven Markov chains (six heated chains, one cold) for $3 \times 10^{6}$ generations, where one tree was retained every 1000 generations. Each analysis reached stationarity (an average standard deviation of split frequencies between runs $<0.01$ ) well before the end of the run. A burn-in sample of 750 trees was removed before calculating the majority rule consensus trees in MrBayes.

\section{RESULTS}

\section{Morphological observations}

Quadricoccopsis simplex Liu, Zhu, Song, Liu, Wang, Liu et Hu sp. nov. (Strain LXD53)

Free-floating colonies contained 4 cells, sometimes 2, and rarely up to 16, when cultured (Fig. 1A). Mother cell walls usually not obviously extended and instead ruptured in time to release the daughter cells. Two pairs of daughter cells adhered to the margin of the mother cell wall respectively by the median portion and the end portion (Fig. 1B) and pulled the mother cell wall remnant into a shallow bowl or broad and short band shape (Fig. 1C, F, G). The colony mucilage was as thick as $3-5 \mu \mathrm{m}$ (Fig. 1D). Mature cells were oval shaped and slightly asymmetric with a broad end and another relatively narrow end. When young, cells were oval to ellipsoid or cylindrical (Fig, 1D, E). Cells ranged in size from 6.04 to $10.26 \mu \mathrm{m}$ long and 3.59 to $7.10 \mu \mathrm{m}$ wide. The parietal chloroplast occurred singly (Fig. 1I) with one large central pyrenoid (Fig. 1E, F). Propagation was by four, or sometimes two, autospores (Fig. 1D). When four, the two pairs of autospores were often diagonal at a forty-five degree angle (Fig. 1D). When the mother cell wall ruptured, one of the pairs was first released and parallelly adhered to the mother cell wall edge by the median portion. The first released pairs often slightly stretched the mother cell wall into a broad and short band shape (Fig. 1E, F). Then, the other pair of cells released by end adherence (Fig. $1 \mathrm{G}, \mathrm{H}$ ) and stretched the openings of the mother cell wall into a square (Fig. 1A, H). When two, the mother cell walls were pulled into a rectangle or $\mathrm{Y}$-shaped band. Sexual reproduction and flagellated stages were not observed.

When observed with TEM, a two-layered cell wall was obvious (Fig. 4A, B). However, no obvious Oocystis-like perpendicular fibril orientations were found (Fig. 4B). The adherence between mother cell wall and daughter cell was observed by mucilage (Fig. 4B). One global pyrenoid with a homogenous matrix was situated in the chloroplast and surrounded by a thick starch sheath that contained five-six starch plates (Fig. 4C). Thylakoids extended the length of the chloroplast

Table 1. Morphological comparisons of three species in genus Quadricoccopsis and five species in genus Lobocystis.

\begin{tabular}{|c|c|c|c|c|c|}
\hline Species & Cell size & $\begin{array}{c}\text { Colony } \\
\text { morphology }\end{array}$ & $\begin{array}{l}\text { Autospore } \\
\text { number }\end{array}$ & $\begin{array}{l}\text { Quadricoccopsis-like } \\
\text { cell connection mode }\end{array}$ & Habitat \\
\hline Q. simplex & $\begin{array}{c}6.04-10.26 \times 3.59- \\
7.10 \mu \mathrm{m}\end{array}$ & $\begin{array}{l}\text { Simple } 4 \text { (or } 2)- \\
\text { celled colony }\end{array}$ & $2-4$ & Yes & limnetic \\
\hline Q.parva & $\begin{array}{c}3.08-5.57 \times 1.79- \\
3.94 \mu \mathrm{m}\end{array}$ & $\begin{array}{c}\text { Simple } 4(\text { or } 2)- \\
\text { celled colony and } \\
\text { sometimes up to } \\
16 \text { cells }\end{array}$ & $2-4$ & Yes & limnetic \\
\hline Q. glomerata & $\begin{array}{c}4.85-8.08 \times 3.10- \\
6.23 \mu \mathrm{m}\end{array}$ & $\begin{array}{l}\text { Large colony } \\
\text { usually with } \\
8-16-64 \text { cells }\end{array}$ & $4-8$, rarely 2 & Yes & limnetic \\
\hline L.planctonica & $8-13 \times 5-8 \mu \mathrm{m}$ & $\begin{array}{l}\text { 2-4-multicelled } \\
\text { colony }\end{array}$ & Constant 2 & No & $\begin{array}{l}\text { limnetic or } \\
\text { haline }\end{array}$ \\
\hline L.neodichotoma & $6-9 \times 2.8-5 \mu \mathrm{m}$ & $\begin{array}{l}\text { Variable number } \\
\text { of cells in colony }\end{array}$ & Constant 2 & No & $\begin{array}{l}\text { Salinity } \\
\text { unclear }\end{array}$ \\
\hline L.fottiana & $9.6-16.4 \times 5-7 \mu \mathrm{m}$ & $\begin{array}{l}\text { Variable number } \\
\text { of cells in colony }\end{array}$ & Constant 2 & No & limnetic \\
\hline L.incospicua & $3.2-6 \times 2.2-3.8 \mu \mathrm{m}$ & $\begin{array}{l}2-4-8-\text { celled } \\
\text { colony }\end{array}$ & Constant 2 & No & haline \\
\hline L.michevii & $3-4.6 \times 1.5-3.5 \mu \mathrm{m}$ & $\begin{array}{l}2-4-(\text { seldom }) 8 \\
\text { celled colony }\end{array}$ & Constant 2 & No & $\begin{array}{l}\text { Mixo- } \\
\text { polyhaline }\end{array}$ \\
\hline
\end{tabular}




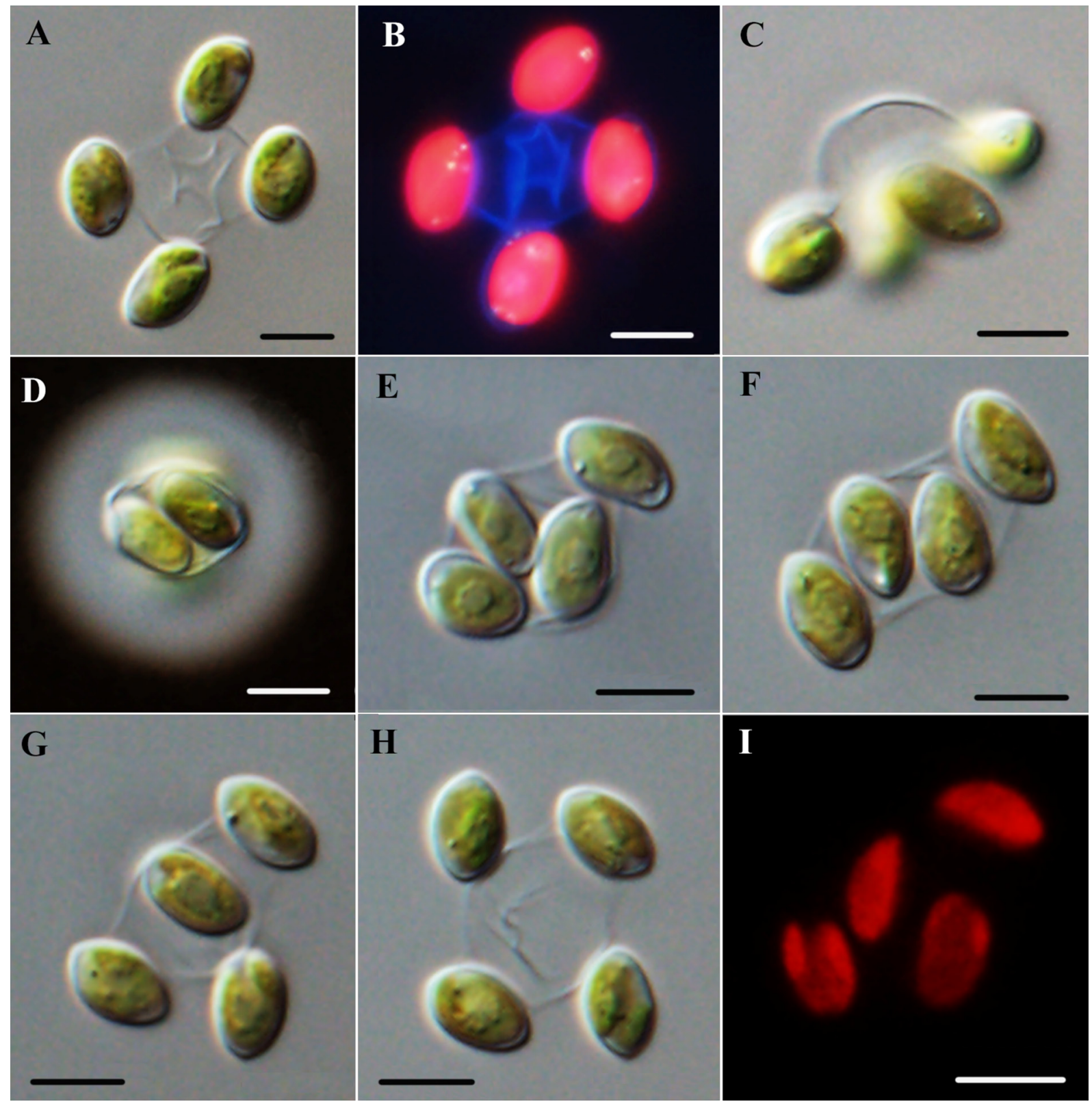

Fig. 1. Light microscopy of Quadricoccopsis simplex: (A) Characteristic 4-celled colony morphology; (B) Colony was stained blue with Fluorescent Brightener to show cell walls; (C) Lateral view of a 4-celled colony to show shallow bowl-shape mother cell remnant; (D) Autospores were stained by ink indicating the mucilage envelope; (E, F) The first released pair of cells exhibited median portion adherence to the mother cell wall, which was stretched into a broad band shape; $(\mathrm{G}, \mathrm{H})$ The pair of cells subsequently released exhibited end portion adherence to the mother cell wall, which was then stretched into a square shape; (I) Autofluorescence shows the shape of chloroplasts. Scale bar $5 \mu \mathrm{m}$.

and occurred in stacks of three to six (Fig. 4C). Starch grains were numerous inside the chloroplast (Fig. 4A, C).

Quadricoccopsis parva LIU, ZHU, Song, LIU, WANG, LiU et Hu sp. nov. (Strain LXD126, LXD135, LXD143) Free-floating colonies contained $2-4-8$ cells (Fig. 2A), and sometimes as many as 16 cells could also be observed (Fig. 2B, C). In the 4-celled group, two pairs of daughter cells adhered to the shallow bowl-shaped mother cell wall respectively by the median portion and the end portion (Fig. 2D). In the 2-celled group, the pair of daughter cells commonly connected to the broad band or Y-shaped mother cell wall by the median portion
(Fig. 2A, G). The colony mucilage was as thick as 3 $\mu \mathrm{m}$. The mature cell was oval and a little asymmetric between the two poles. The young cells and autospores were ellipsoid to cylindrical (Fig. 2B, C, F). Cell size ranged from 3.08-5.57 $\mu \mathrm{m}$ long and 1.79-3.94 $\mu \mathrm{m}$ wide. The surface incrustations were common on the cell walls, especially on the empty mother cell walls, when in the field (Fig. 2A, B) but rare when cultured (Fig. $2 \mathrm{G})$. The granules at the cell surfaces were red-brown, irregularly spherical, unequally sized and non-uniformly distant from each other. The granules were sometimes clustered alongside to form interrupter ribs (Fig. 2A, B, $\mathrm{G})$. The partial chloroplast was singly and lobed with 


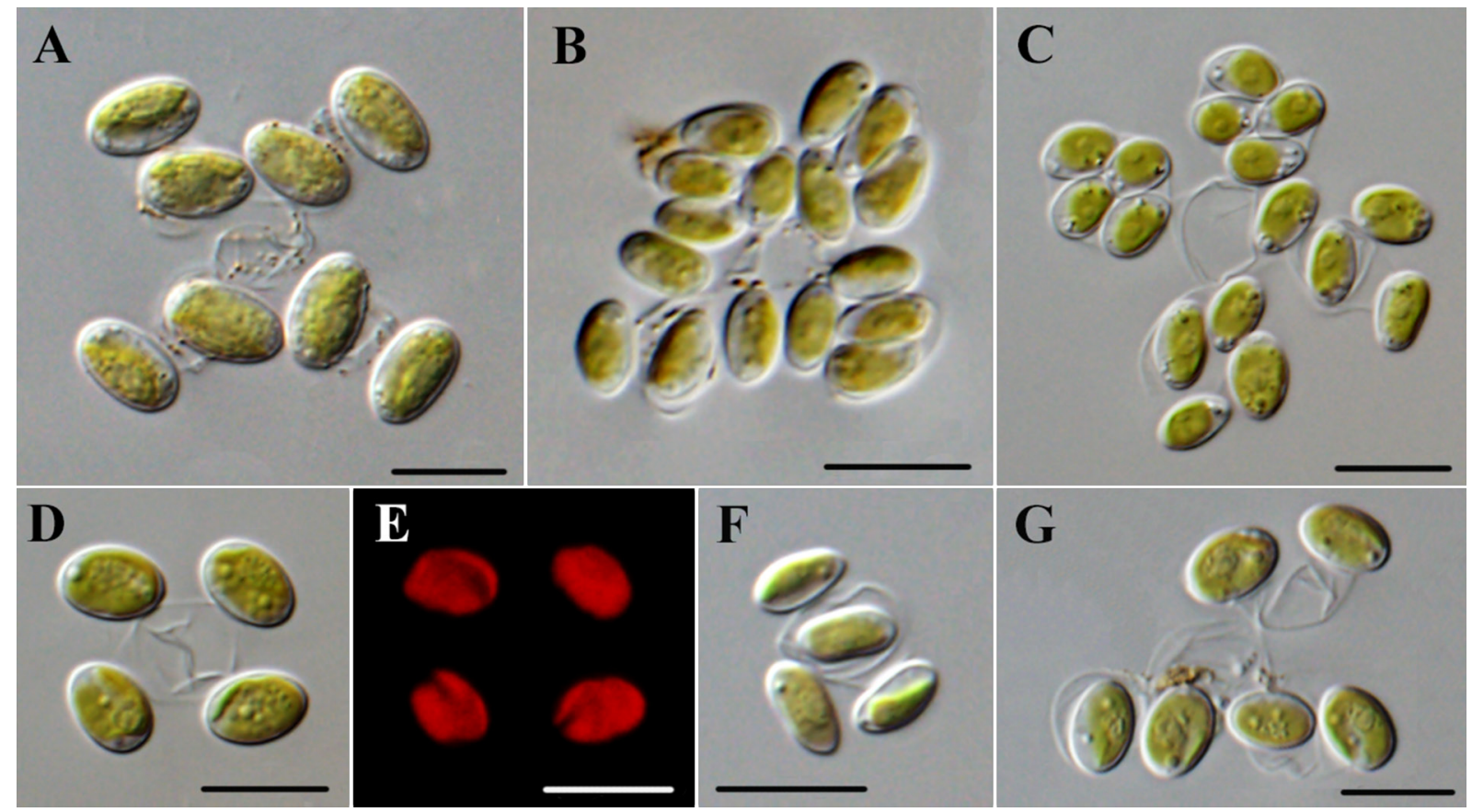

Fig. 2. Light microscopy of Quadricoccopsis parva: (A) Colony in the field; (B) Colony with young cells in the field; (C) 16-celled colony cultured in the laboratory; (D) Characteristic 4-celled colony; (E) Autofluorescence shows the shape of chloroplasts; (F) Young cell colony; (G) Colony with granules in the mother cell wall when cultured. Scale bar $5 \mu \mathrm{m}$.
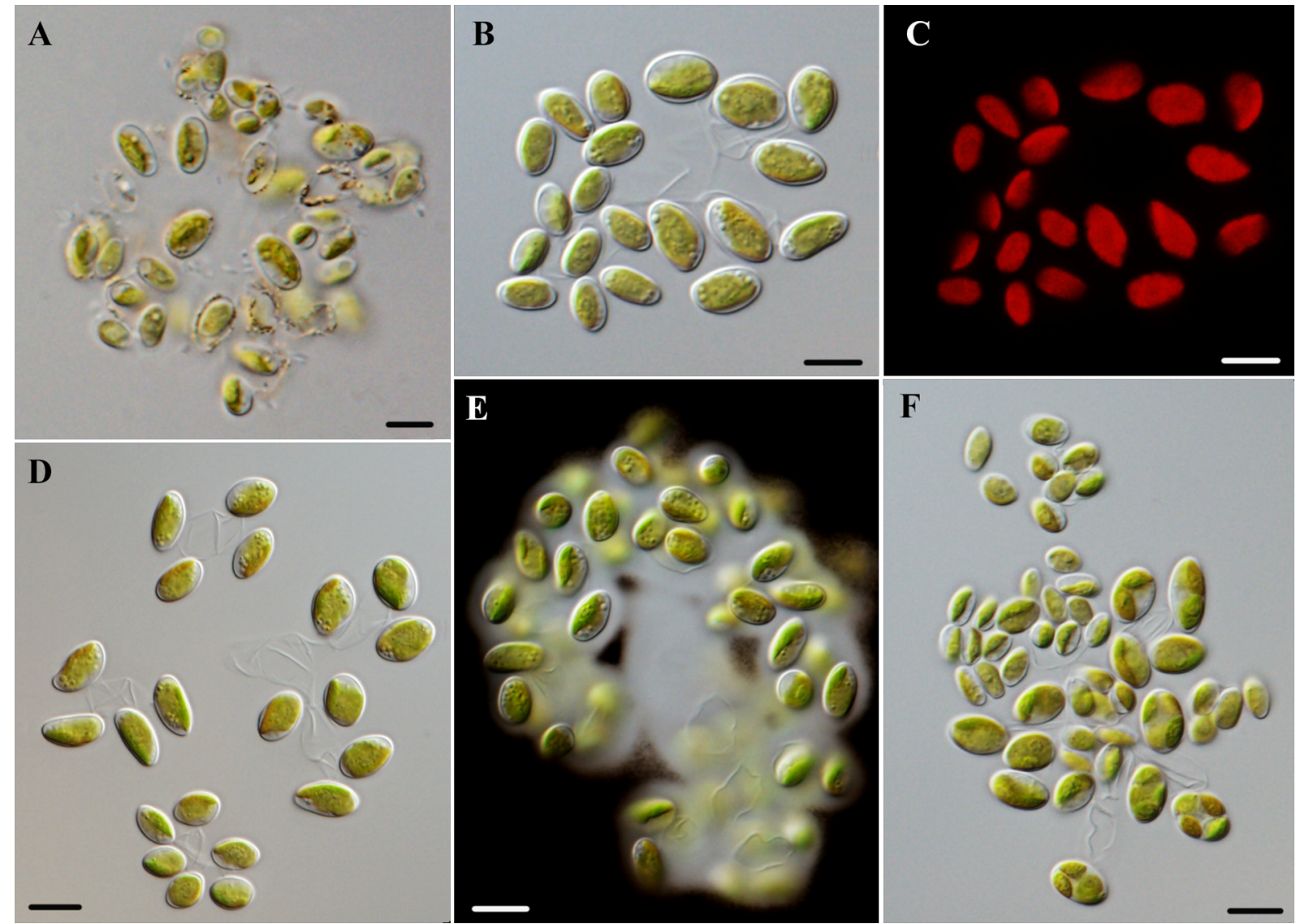

F

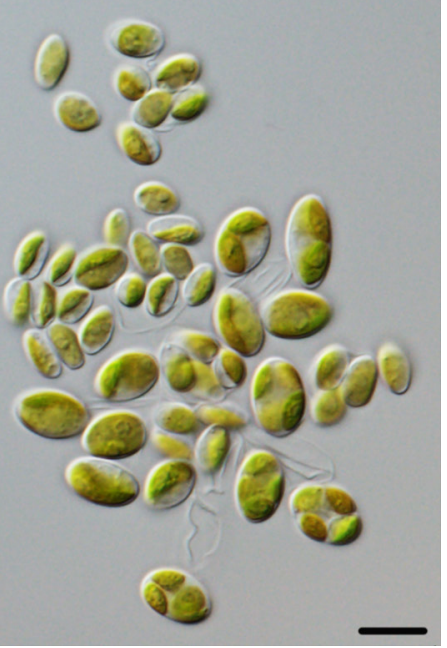

Fig. 3. Light microscopy of Quadricoccopsis glomerata: (A) Colony in the field; (B) Colony cultured in the laboratory; (C) Autofluorescence shows the shape of chloroplasts; (D) Characteristic 4-celled colony and Y-shaped mother cell wall stem; (E) Colony was stained by ink indicating the mucilage envelope; (F) Large colony when cultured. Scale bar $5 \mu \mathrm{m}$. 

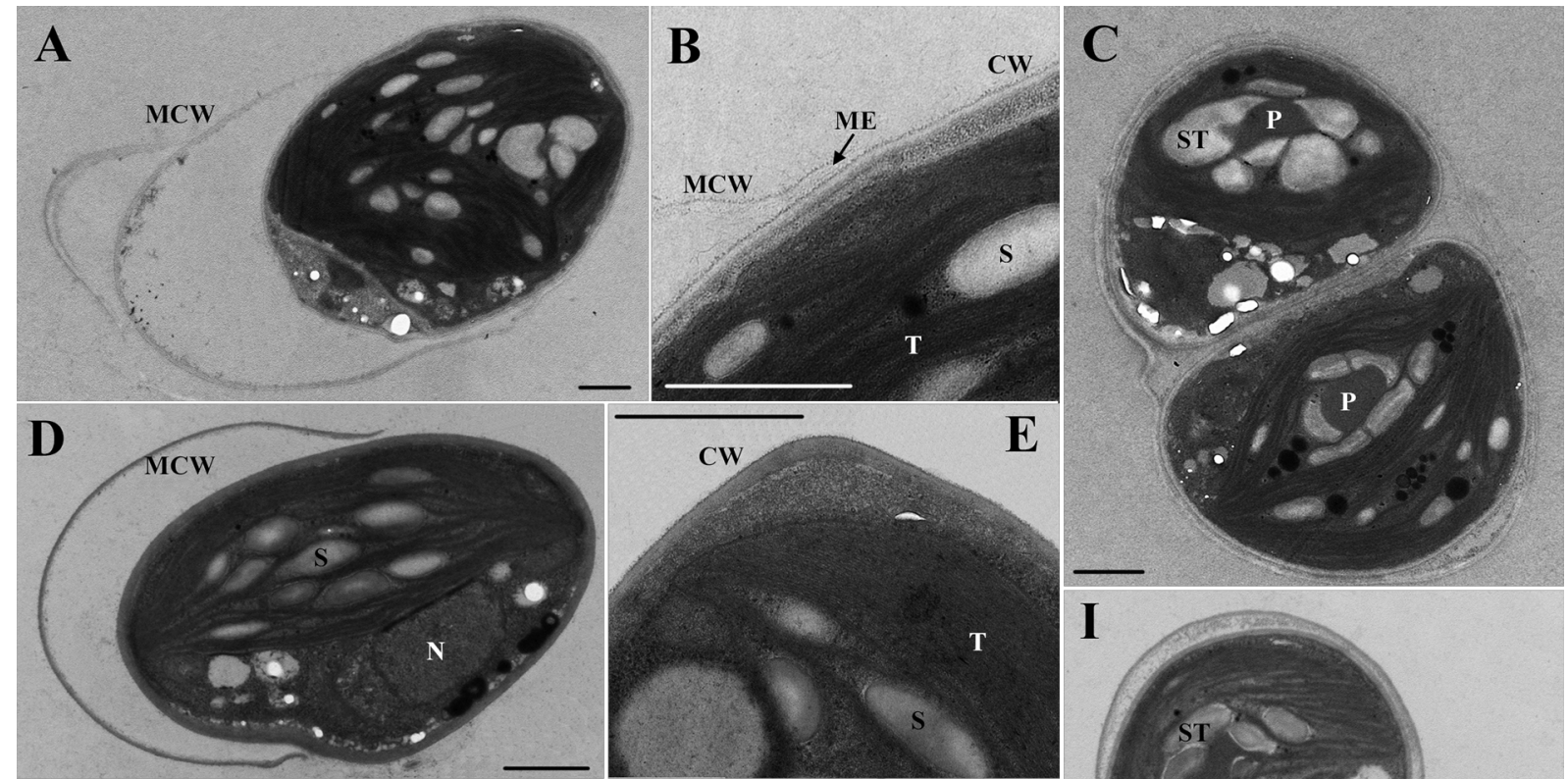

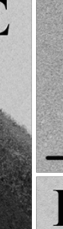
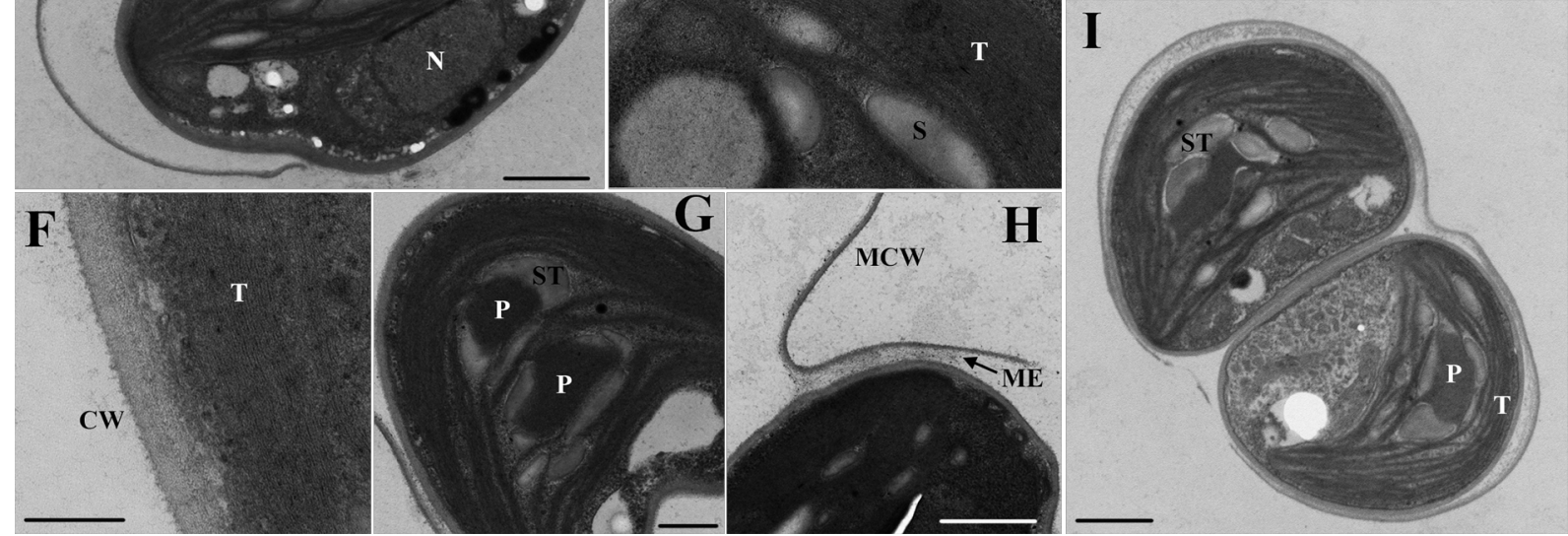

Fig. 4. Transmission electron microscopy of Quadricoccopsis simplex (A-C) and Quadricoccopsis glomerata (D-I): (A) Daughter cell connected by mother cell walls; (B) Details of the cell wall and adherence to mother cell wall by mucilage; (C) Details of two-celled autospores; (D) Daughter cell connected by mother cell walls; (E) Details of the tapered end; (F) Details of a cell wall; (G) Details of pyrenoids; (H) Details of the cell wall adherent with mother cell wall by mucilage; (I) Details of two-celled autospores. Scale bar $1 \mu \mathrm{m}$ (A-E, H, I), $0.5 \mu \mathrm{m}(\mathrm{G})$ and $0.1 \mu \mathrm{m}$ (F).

a pyrenoid (Fig. 2E). Propagation was by two to four autospores. Sexual reproduction and flagellated stages were not observed.

Quadricoccopsis glomerata Liu, Zhu, Song, Liu, Wang, Liu et Hu sp. nov. (Strain LXD117, LXD134, LXD144) Larger colonies usually contained more than 16 cells, which were basically formed by 4 or 8 -celled small groups (Fig. 3A, B). When cultured, the simple 4-celled colony could be observed sometimes (Fig. 3D). The primary mother cell wall often ruptured and was stretched by groups into a broad band or $\mathrm{Y}$-shaped stalk (Fig. 3D) or irregular strand (Fig. 3A, B, F). In each group, the secondary mother cell walls were a shallow bowl-shape and the Quadricoccopsis-like cell arrangement was obviously that two pairs of daughter cells adhered to the mother cell wall respectively by the median portion and the end portion (Fig. 3D). The colony mucilage was thick (Fig. $3 \mathrm{E})$. The cells were ovals to long ellipsoids and slightly curved with tapered ends sometimes (Fig. 3D), 4.85-8.08 $\mu \mathrm{m}$ long and 3.10-6.23 $\mu \mathrm{m}$ wide. The irregular granules at the cell surfaces were common when in the field and sometimes clustered alongside to form interrupter ribs (Fig. 3A). The pyrenoid-bearing chloroplast occurred parietally and singly (Fig. 3C). Propagation was by four or eight autospores (Fig. 3B, F). Sexual reproduction and flagellated stages were not observed.

When observed with TEM, the mother cell walls were found adhered to the daughter cells by mucilage (Fig. 4D, H). The Oocystis-like cell wall ultrastructure was not obvious (Fig. 4E, F). One or two global pyrenoids with a homogenous matrix were situated in the chloroplast and surrounded by a thick starch sheath that contained three-five starch plates (Fig. 4G, I). Starch grains were numerous inside the chloroplast (Fig. 4D, I).

\section{Phylogenetic analyses}

$18 \mathrm{~S}$ rDNA and $r b c \mathrm{~L}$ cpDNA sequences were obtained for these seven strains. Sequencing of the 18S rDNA PCR product of Quadricoccopsis simplex produced a 2952 bp sequence containing three introns. The three 18S rDNA sequences of Quadricoccopsis parva were 2856 bp (LXD126), 2858 bp (LXD135) and 2969 bp (LXD143), all including three introns. The same genes from three strains of Quadricoccopsis glomerata were 2446 bp (LXD117), 2610 bp (LXD134) and 2332 bp (LXD144) in length, all with one intron. Introns were not found in $r b c \mathrm{~L}$ cpDNA sequences. Sequences obtained herein were submitted to GenBank under accession numbers MG674833-MG674848. 


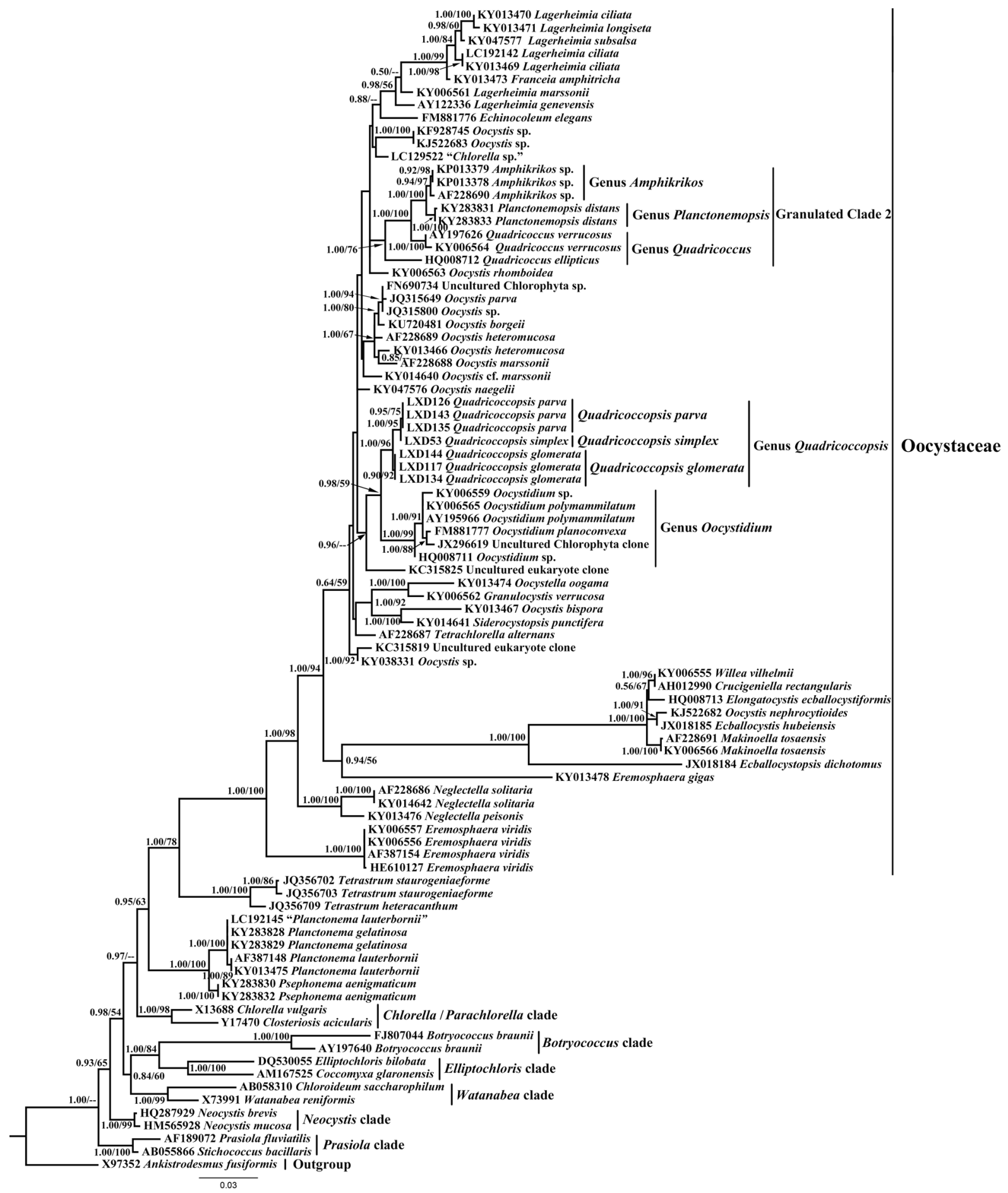

Fig. 5. Phylogenetic tree of $18 \mathrm{~S}$ rDNA sequences from Trebouxiophyceae species. Bootstrap support from Bayesian inference (BI) posterior probabilities and maximum likelihood (ML, constructed by RAxML) are presented on the nodes in order. Values above 0.5 for BI and 50 for ML are shown.

The final alignment of the $18 \mathrm{~S}$ rDNA exon regions included the main taxa in Trebouxiophyceae. Ankistrodesmus fusiformis CORDA (Chlorophyceae) was chosen as the outgroup. The aligned $r b c \mathrm{~L}$ cpDNA sequences included the most closely related members of the taxa Oocystaceae and Chlorellaceae. Ankistrodesmus falcatus (CORDA) RALFS (Chlorophyceae) was chosen for the outgroup.

The ML and Bayesian analyses yielded similar topologies and only one was present. The $18 \mathrm{~S}$ rDNA phylogenetic trees and the $r b c \mathrm{~L}$ cpDNA trees both showed the genus Quadricoccopsis in Oocystaceae as a sister to genus Oocystidium KorshiKov (Fig. 5, 6). The genus Quadricoccopsis was also resolved separating from genus Quadricoccus in different lineages (Fig. 5). Three different species of genus Quadricoccopsis were also revealed by both trees with good supports (Fig. 5, 6). 


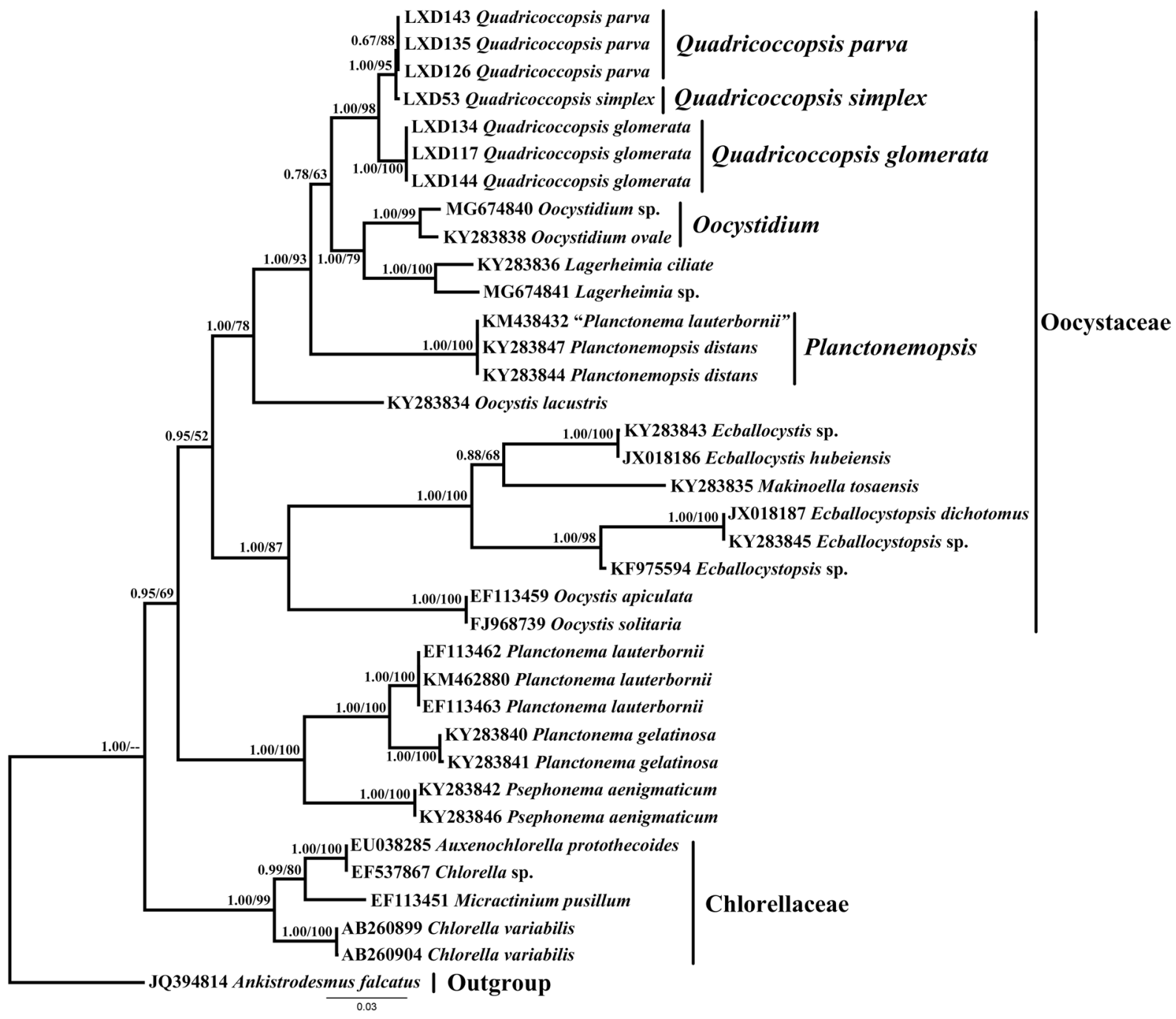

Fig. 6. Phylogenetic tree of $r b c \mathrm{~L}$ cpDNA sequences from Oocystaceae and Chlorellaceae species. Bootstrap support from Bayesian inference (BI) posterior probabilities and maximum likelihood (ML, constructed by RAxML) are presented on the nodes in order. Values above 0.5 for $\mathrm{BI}$ and 50 for ML are shown.

\section{DisCUSSION}

In the small artificial waterbody, members of Quadricoccuslike algae were quite common throughout the year. Recently, a new member of this group was found in four different places in China. Morphological comparison of similar taxa combined with the molecular analyses for it led to the erection of the new genus Quadricoccopsis within the Oocystaceae (Trebouxiophyceae).

Within the subfamily Dictyospaerioideae (KoMÁREK \& FOTT 1983), which were all characteristically distinguished by mother cell wall remnant connections in colony formation, the oval to cylindrical cell shape is only found in the Dictyosphaerium-like group (KRIENITZ et al. 2010), genus Quadricoccus and genus Lobocystis. Genus Quadricoccopsis can be easily differed from the Dictyosphaerium-like group by colony development. The mother cell wall of the Dictyosphaerium splits into as many segments as there are autospores (often four or sometimes two) and each of the latter remains adhered to the tip of a segment (THOMPSON 1952; KomÁREK \& FOTT 1983). Relatively, the mother cell wall of Quadricoccopsis does not segment but produces only simple rupture to release daughter cells and then maintains a shallow bowl-like shape similar to the genus Quadricoccus. However, compared with Quadricoccus, the genus Quadricoccopsis distinguishes itself by a characteristic adherent mode of the daughter cells on the empty mother cell wall. Members of Quadricoccus can be differentiated into two groups by the adherent portion: the pole adherent, including type species $Q$. verrucosus, $Q$. laevis and $Q$. euryhalinicus, and the median adherent, including $Q$. ellipticus and $Q$. ovalis. The differentiating mode of Quadricoccopsis is two pairs of daughter cells connected to the mother cell remnant respectively by the pole and the median portion. In addition, molecular phylogenetic analysis resolved these two genera in two different clades in Oocystaceae. According to the latest special study on Oocystaceae of ŠTENCLOví et al. (2017), the Quadricoccus, represented by the type 
species $Q$. verrucosus and $Q$. ellipticus, was positioned in one of the granulated clades (Granulated Clade 2) in Oocystoideae. Our phylogenetic analysis yielded similar topology. Genus Quadricoccopsis was resolved in the Oocystidium clade with a close relationship with genus Oocystidium and separated from granulated clade 2. As far as the other similar genus Lobocystis, though the disputes were still on the type species (HINDÁK 1977; COMAS \& PEREz 2002), the point, proposed by KomÁreK \& FotT (1983) and HindÁK (1988) that reproduction by constant formation of two autospores, was considered according with all the well-defined members and therefore reasonable to be a generic feature (KOMÁREK \& FotT 1983; HINDÁK 1988). Our new genus was different from Lobocystis by variable 2-4-8 autospores (Table $1)$. In fact, the 4 autospores was more common by our observation in all species of Quadricoccopsis. Moreover, the characteristic Quadricoccopsis-like cell connection mode, that is two pairs of daughter cells connected to the mother cell remnant respectively by the pole and the median portion, was not observed by well-defined members of genus Lobocystis. In relation to the ecology, Quadricoccopsis was only found in limnetic water but the Lobocystis could exist in limetic, oligohaline and even haline water (STOYNEva 2008).

In fact, some of the suspicious members in genus Lobocystis may be placed in the genus Quadricoccopsis. An undefined Lobocystis sp., described by KOMÁREK in 1974 with a 4-celled colony morphology of two pairs of cells connected to the mother cell wall respectively by the median and the end portion (KOMÁREK \& FOTT 1983; IZAGUIRRE 1991) seems identical to the type species Quadricoccopsis simplex. However, because of a lack of strains, we are not in a position to determine whether the species mentioned above should be grouped into the genus Quadricoccopsis.

Within genus Quadricoccopsis, three species are identified and phylogenetically and morphologically distinguished. The morphology mainly differentiated by cell size, colony morphology and number of autospores (Table 1). The type species $Q$. simplex is distinguished from others by a larger cell size and a simple 4(or 2)-celled colony. In contrast, $Q$. parva showed a smaller cell size and $Q$. glomerata had an obviously larger colony cell number and more autospores. The granules on the cell surfaces of Quadricoccopsis proved to be variable. In the field condition, the granules are common but vary in number and size and can be smooth to dense along the entire surface. However, when cultured, the granules often disappear. They even can be observed, or not observed, in one species and one culture medium. Just as mentioned by HiNDÁK $(1984 ; 1988)$, the granules are a result of iron deposits, the occurrence, or not, of which depends on the chemical properties of the environment.

The Oocystaceae, as summarized by KoMÁREK \& FOTT (1983), are traditionally characterized by an Oocystis-like cell wall ultrastructure that is multi-layered with cellulose fibrils in each layer perpendicular to those of the adjoining layer. However, though some genera were affirmed to possess the ultrastructure (Š́TENCLOvá et al. 2017), the Planctonema-like algae, including the genus Planctonemopsis Liu et Liu, which was positioned within the core Oocystaceae, was an exception (ŠTENCLOví et al. 2017; LiU et al. 2017). The genus Quadricoccopsis also shows no obvious Oocystis-like ultrastructure by our research herein. The different colony formation mechanism, daughter cell connection by mucilage adherence to the ruptured mother cell wall remnant (genera Planctonemalike algae and genus Quadricoccopsis) compared with the daughter cells enclosed by an expanded mother cell wall (Oocystis-like genera), may explain the distinction. The Oocystis-like multi-layered interwoven mother cell wall is considered more avail to expansion. Therefore, whether the ultrastructual criterion could be applied to all Oocystaceae members requires further study.

\section{Taxonomic implications}

Quadricoccopsis Liu, Zhu, Song, Liu, Wang, Liu et Hu gen. nov.

Description: Colony free-floating, 2-4-16-64 cells and formed by four (sometimes two) cell groups. Two pairs of cells adhere to the margin of the mother cell wall respectively by the median portion and the end portion in a 4-celled group and often by the median portion in a 2-celled group. Cells are oval, elliptical or cylindrical and slightly asymmetric. The irregular granules exist on the cell walls when in the field but rarely when cultured. Single chloroplast, parietal, with one or two pyrenoids. Propagation by 2-4-8 autospores. Genus differs from Quadricoccus by colony cell organization: two pairs of cells adhere to the mother cell walls characteristically by the median portion and the end portion, respectively. Genus differs from Lobocystis by variable 2-4-8 autospores, characteristically cell adherent mode and only found in limnetic water.

Etymology: The genus is named for similar morphology with genus Quadricoccus.

Type species: Quadricoccopsis simplex

Quadricoccopsis simplex Liu, Zhu, Song, Liu, Wang, Liu et Hu sp. nov.

Description: Colony formed by 4 cells, sometimes 2, and rarely 16 . Cells 6.04 to $10.26 \mu \mathrm{m}$ long and 3.59 to $7.10 \mu \mathrm{m}$ wide. Single chloroplast parietal, with one large central pyrenoid. Propagation by 2-4 autospores. Species differs from others usually by a simple four or two cell colony and larger cell size.

Holotype: Formaldehyde-fixed material was stored at the Freshwater Algal Herbarium (HBI), Institute of Hydrobiology, Chinese Academy of Science, Wuhan, China, as specimen No. LXD53.

Reference strain: A living culture was deposited in the Freshwater Algae Culture Collection, Institute of Hydrobiology, Chinese Academy of Science, Wuhan, 
China (FACHB) as strain FACHB-2252.

Type locality: Yingze Lake $\left(37^{\circ} 51^{\prime} \mathrm{N}, 112^{\circ} 33^{\prime} \mathrm{E}\right.$, alt. 792 $\mathrm{m})$, Taiyuan, Shanxi Province, China. Water samples were collected in Aug. 2015.

Etymology: The species is named for its usually simple four or two cell colony.

Quadricoccopsis parva Liu, Zhu, Song, Liu, Wang, Liu et Hu sp. nov.

Description: Colony formed by $2-4$ cells, sometimes 16. Cells 3.08-5.57 $\mu \mathrm{m}$ long and 1.79-3.94 $\mu \mathrm{m}$ wide. Single chloroplast parietal, lobed, with one pyrenoid. Propagation by 2-4 autospores. Species differs from others by its small cell size and occasional large colony of up to 16 cells.

Holotype: Formaldehyde-fixed material was stored at the Freshwater Algal Herbarium (HBI), Institute of Hydrobiology, Chinese Academy of Science, Wuhan, China, as specimen No. LXD143.

Reference strain: A living culture was deposited in the Freshwater Algae Culture Collection, Institute of Hydrobiology, Chinese Academy of Science, Wuhan, China (FACHB) as strain FACHB-2253.

Type locality: An artificial pond $\left(31^{\circ} 6^{\prime} \mathrm{N}, 115^{\circ} 42^{\prime} \mathrm{E}\right.$, alt. 348 m) in Luotian, Hubei Province, China. Water samples were collected in Aug. 2017.

Etymology: The species is named for its smaller cell size.

\section{Quadricoccopsis glomerata Liu, Zhu, Song, Liu, Wang, Liu et Hu sp. nov.}

Diagnosis: Colony formed by 4-16-64 cells. Cells oval, slightly curved, 4.85-8.08 $\mu \mathrm{m}$ long and 3.10-6.23 $\mu \mathrm{m}$ wide. Single chloroplast parietal, with one or two pyrenoids. Propagation by 4-8 autospores. Species differs from others by its larger colony with more cells and more autospores when propagating.

Holotype: Formaldehyde-fixed material was stored at the Freshwater Algal Herbarium (HBI), Institute of Hydrobiology, Chinese Academy of Science, Wuhan, China, as specimen No. LXD144.

Reference strain: A living culture was deposited in the Freshwater Algae Culture Collection, Institute of Hydrobiology, Chinese Academy of Science, Wuhan, China (FACHB) as strain FACHB-2254.

Type locality: A fish pond $\left(30^{\circ} 55^{\prime} \mathrm{N}, 115^{\circ} 31^{\prime} \mathrm{E}\right.$, alt. 120 $\mathrm{m})$ in Luotian, Hubei Province, China. Water samples were collected in Aug. 2017.

Etymology: The species is named for its often larger colony with more cells.

\section{ACKNOWLEDGMENTS}

This project was supported by the National Natural Science Foundation of China (No. 31670202) and special foundation for biodiversity conservation of China's Ministry of Environmental Protection.

\section{REFERENCES}

Comas gonzalez, A. \& Perez baliero, M.D. (2002): Chlamydophyceae (Chlorophyceae) from Merin lagoon (Brazil-Uruguay, South America) with special references to the family Botryococcaceae. - Algological Studies 145: 49-65.

Fanés Treviño, I.; SÁnchez CASTillo, P.M. \& Comas GonZÁlez, A. (2009): Contribution to the taxonomical study of the family Botryococcaceae (Trebouxiophyceae, Chlorophyta) in southern Spain. - Cryptogamie. Algologie 30: 17-30.

FuČíKovÁ, K.; FLECHTNER, V.R. \& LewIS, L.A. (2013): Revision of the genus Bracteacoccus Tereg (Chlorophyceae, Chlorophyta) based on a phylogenetic approach. Nova Hedwigia 96: 15-59.

GuirY, M.D. \& GuiRY, G.M. (2017): AlgaeBase. World-wide electronic publication. - National University of Ireland, Galway. http://www.algaebase.org; searched on 16 November 2017.

Hindák, F. (1977): Studies of the chlorococcal algae (Chlorophyceae). - I. Biologické Práce 23: 1-190.

HiNDÁk, F. (1984): Studies of the chlorococcal algae (Chlorophyceae). - III. Biologické Práce 30: 1-308.

HiNDÁk, F. (1988): Studies of the chlorococcal algae (Chlorophyceae). -IV. Biologické Práce 34: 1-262.

Hoshaw, R.W. \& Rosowski, J.R. (1973): Isolation and purification. 3: Methods for microscopic algae. -In: J.R. Stein (ed.): Handbook of Phycological Methods. Culture Methods and Growth Measurement. - pp. 53-67, Cambridge University Press, New York.

HuElSENBECK, J.P. \& RoNQUIST, F. (2001): MRBAYES: Bayesian inference of phylogenetic trees. - Bioinformatics 17: $754-755$.

IzAGUIRRE, I. (1991): A revision of the genus Lobocystis THOMPSON (Chlorococcales). - Cryptogamic Bot 2: 269-273.

KomÁreK, J. \& FotT, B. (1983): Chlorophyceae (Grünalgen) Ordnung: Chlorococcales. - In: Huber-Pestalozzi, G. (ed.): Das Phytoplankton des Süßwassers 7. Teil, 1. Hälfte. - 1044 pp., Schweizerbart'sche Verlagsbuchhandlung (Nägele u. Obermiller), Stuttgart.

Krienitz, L.; Bock, C.; Luo, W. \& Pröschold, T. (2010): Polyphyletic origin of the Dictyosphaerium morphotype within Chlorellaceae (Trebouxiophyceae). - Journal of Phycology 46: 559-563.

KRIENITZ, L. \& BoCK, C. (2011): Elongatocystis ecballocystiformis gen. et comb. nov., and some reflections on systematics of Oocystaceae (Trebouxiophyceae, Chlorophyta). - Fottea 11: 271-278.

Kuylenstierna, M. \& Karlson, B. (1998): Quadricoccus euryhalinicus sp. nov. (Botryococcaceae, Chlorophyceae), an euryhaline green alga from the Skagerrak, northeast Atlantic Ocean. - Botanica marina 41: 317-320.

Larkin, M.A.; Blackshields, G.; Brown, N.P.; Chenna, R.; Mcgettigan, P.A.; Mcwilliam, H.; Valentin, F.; Wallace, I.M.; Wilm, A.; LoPEZ, R.; ThOMPSON, J.D.; Gibson, T.J. \& Higgins D.G. (2007): Clustal W and Clustal X version 2.0. - Bioinformatics 23: 2947-2948.

Liv, X.; Zhu, H.; Liv, B.; Liv, G. \& Hu, Z. (2017): Classification of planctonema - like algae, including a new genus Planctonemopsis gen. nov., a new species Planctonema gelatinosum sp. nov. and a reinstated genus Psephonema (Trebouxiophyceae, Chlorophyta). - Journal of Phycology 53: 869-879. 
NylandeR, J.A.A. (2004): MrModeltest ver. 2.3. Program distributed by the author. - Evolutionary Biology Centre, Uppsala University, Sweden.

Reynolds, E.S. (1963): The use of lead citrate at high pH as an electron-opaque stain in electron microscopy. - J. Cell. Biol. 17: 208-212.

STAMATAKIS, A. (2014): RAxML version 8: a tool for phylogenetic analysis and post-analysis of large phylogenies. - Bioinformatics 30: 1312-1313.

Stanier, R.Y.; Kunisawa, R.; MANDel, M. \& COHen-Bazire, G. (1971): Purification and properties of unicellular blue-green algae (order Chroococcales). - Bacteriological Reviews 35: 171-205.

Štenclová, L.; Fučíková, K.; Kaštovský, J. \& Pažoutová, M. (2017): Molecular and morphological delimitation and generic classification of the family Oocystaceae (Trebouxiophyceae, Chlorophyta). - Journal of phycology 53: 1263-1282.

Stoyneva, M.P. (2008): Lobocystis michevii (Chlorophyceae)-a New Green Algal Species from the Bourgas salines (Bulgaria). - Phyton (Horn, Austria) 48: 79-86.

Thompson, R.H. (1952): A new genus and new records of algae in the Chlorococcales. - American Journal of Botany: 365-367.

Williams, E.G. (1967): Notes on three algae of small bodies of water. - British Phycological Bulletin 3: 337-342.

XIA, S.; Zhu, H.; ChenG, Y.Y.; LiU, G.X. \& Hu, Z.Y. (2013): Phylogenetic position of Ecballocystis and Ecballocystopsis (Chlorophyta). - Fottea 13: 65-75.

(C) Czech Phycological Society (2018)

Received December 30, 2017

Accepted April 20, 2018 